\title{
Behavioural Determinants of Impulse Buying - An Empirical Study of a Metropolitan Hub of Pakistan
}

\author{
Mubbashir Munir \\ University of Management and Technology \\ Manzir Abbas \\ Istanbul Okan University
}

Kenneth A. Grant

Ryerson University

Noman Arshed

University of Management and Technology

Osama Aziz

Ryerson University

Unpredictable shopping expenses take a toll on family's monthly budget in poor economies like Pakistan. Studying the determinants to these uncalled and impulsive shopping urges is of the essence when the objective is to plan for the future. This study explores the main factors affecting consumers' unplanned buying from departmental stores in Pakistan's metropolitan city. The indicators included buying behaviour, customers' emotions, promotion \& advertisement, physical environment, and price of products. The objective was set to examine the leading factors influencing customers to buy in departmental stores (Metro Cash and Carry, Al- Fateh and Hyper Star) of Lahore, Pakistan. The survey approach was taken in this study through a convenience sampling design with a sample size of 250. The estimation results of median regression were derived from the conclusion by using the SPSS software. The results support policy makers in developing social and economic regulations that assist individuals in avoiding impulse buying.

Keywords: unplanned buying, emotions, promotional \& advertisement, selling behaviour

\section{INTRODUCTION}

Impulse buying is something that is usually bought unplanned and in a larger quantity. When a person goes shopping, different factors affect the mental level that compels him to buy on a larger and unplanned scale. Nowadays, it is prevalent as many superstores up and running, where people often go for pleasure and leisure purposes. This has become a trend in society which is forcing people to go shopping often on impulse. One who shops to make such leverage is mentioned as a nervous impulse vendee or impulse 
consumer. According to major research findings, emotional feelings play a very impactful role in unplanned buying and product advertisement. Furthermore, this is extensively exploited by marketers and retailers, making people buying products unintentionally (Verma \& Badgaiyan, 2015). Mostly these products are related to the general need of people like clothing, accessories, food, etc. Impulse buying takes over the rational decision-making of the buyer, taking away the planned savings. The only prevention of impulse buying is to decide a budget before going out shopping. After reviewing several international research studies, few factors have been selected for the work. Hausman (2000) explained that some state of affairs and retail ambiance influence both memory reaction and the consumers' future depot choice decision. Because of the changing and dynamic nature of expectations, orientation, and behaviour. In-Store promotions (Gutierrez, 2004), people (Ghosh et al., 2010), advertisement (Srinivasan, 2008), lighting (Areni \& Kim, 1994; Summers \& Hebert, 2001; Magnum, 1998), and other factors like music, fragrancy, eight senses of colour, etc. Several internal factors induce the consumers to buy unintentionally. It includes moods and emotions (Watson \& Tellegen, 1985; Beatty \& Ferrell, 1998; Hausman, 2000; Rook et al., 1993; Youn \& Faber, 2000), self-image (Sirgy, 1982), culture and regret (Piron, 1991), and shopping enjoyment (Beatty \& Ferrell, 1998; Stern, 1962). These studies realized that the merchandise which is purchased impulsively often has cheap damage. Lastly, the concept of advertisements that trigger the buyer's impulsive buying behaviours was initially designed to generate extra revenue out of rich customers. Unfortunately, most poor customers are trapped in impulsive buying because of the awareness difference between rich and poor customers.

Based on these facts, the objectives set by this study are to find out how different factors affect consumers for unplanned buying. This study will focus on the customers of big departmental stores of Lahore, Pakistan, which include Metro Cash and Carry, Al-Fateh, and Carrefour. The idea behind this is that Pakistan is becoming a consumer-oriented economy where most consumption expenditures are directed to imports-based commodities. Exploring the means to induce impulse buying, which the wholesale and large retail vendors exploit, could help create awareness to curb these means to extract unplanned incomes out of the low-income buyers. This study would suggest means for individuals and policymakers to stabilize the consumption expenditure patterns at the micro-level. At the macro-level, this study will help the country curtail import-based consumption, which will reduce the devaluating pressures on the national currency and minimizing the burden of debt because of exchange rate devaluation.

\section{LITERATURE REVIEW}

The main issue this study discussed and understood is buying behaviour through impulse. According to Tremblay (2005) and Baumesiter (2002), impulse buying is any intention to purchase a shopper; without purchasing a product, someone feels the urge to buy it. On the other hand, if we see Pakistani consumers' behaviour pattern, they are most likely to buy impulsively when there is a sale or bundle buy products offered by a shipping store (Raheem \& Vishnu, 2013). The window of income level visualizes that merchandising's impact significantly influences consumers' behaviour when the store's environment is pleasant, calm, and decorated along with its surroundings (Verma \& Badgaiyan, 2015; Prajapati \& Thakor, 2012). The most subconscious consumer's objective is to assign the values to a product based on its packing, shape, colour and known awareness of the raw materials used (Arshed, Alamgir, et al., 2017; Arshed, Riaz, Hassan, et al., 2017; Ghaffar et al., 2020; Grant, Croteau, et al., 2019a). This is because different elements of packing have different implications on users mind along with various demographic variables like age, education, gender, and professional environment (Valaei, \& Nikhashemi, 2017; Badgaiyan, Vrama, \& Dixit, 2016; Vyas, 2015; Vrama, \& Badgaiyan, 2015; Bhakat \& Muruganantham, 2013; Hasnu \& Ali, 2013). Instead of that, the need for online impulse buying study on the internet is also increasing the importance of this medium to gain optimum level sale through this channel (Khawaja, 2018; Parsad et al., 2017; Prashar et al., 2017). Around two-thirds of the population in European countries make an online purchase due to the influence of impulse buying. This purchase pattern is mostly focused on the clothing, sports garments, and fashion industries because it rationally urges the buying behaviour (Mahalakshmi, \& Kathiravan, 2019; Ali \& Sudan, 2018; Ahmad et al., 2019). However, the rational choices of decision 
making are consumer's trends to search for important information to make their final buying decisions, and the influence of impulse buying on consumers behaviour increase the values of departmental stores as well, due to their advertisements while providing up to date information to their target consumers (Ahmad et al., 2019; Ali \& Sudan, 2018; Atulkar \& Kesari, 2018; Pornpitakpan, Yuan \& Han, 2017).

The main objective of packing the product is to help the consumers identify, choose, and show an impression regarding the purchase and repurchase of any product. It shows a positive influence on consumer's responses about the product, which leads the consumer towards impulsive buying. It also helps in distinguishing between different brands (Ferguson, Chatfield, Brimblecombe, Liberato, Gunther, Ball, \& Leach, 2017; Cho et al., 2014). While browsing in-store and identifying consumers' positive mood are the main sturdiest predictors of influencing impulse buying behaviour (Grant, Croteau, et al., 2019b; Hanif et al., 2020; Tara et al., 2020). As the positive mood inspires them to move and search-in the store with intend to buy. It encourages individual consumers to have referenced friends, with whom the shopping is mostly done like friends, family, and peers. And respond to more favourably to surroundings products to evaluate the stimulus exposure (Troung, \& Buaphiban, 2017; Azim, 2013). Consumers mostly have a high proneness attitude while dealing at the presence of a good energetic environment of the store that makes an impulse purchase. To increase consumers' buying behaviour, retailers keep a pleasant store environment for their consumers inside their store place to attract the right consumers (Bashir et al., 2013). Different products' packaging strategies exert influence while purchasing as they communicate about a brand or promote a brand. The lifestyle and cultural values influence impulse buying behaviour in the case of Pakistani consumers positively. The relationship among all the cultural variables and lifestyles is significant (Arshed et al., 2020; Aziz et al., 2020; Grant, Aziz, et al., 2019). It suggests that the impulse buying behaviour is predicted by life satisfaction, security, financial satisfaction, gender role, group contact and lifestyles of cultural values as well as the lifestyles of Pakistani consumers (Truong \& Buaphiban, 2017; Alauddin, Hossain, Ibrahim, \& Hoque, 2015; EKeng et al., 2012). According to Saraswat (2012) and Chen (2008), demographic characteristics have a strong impact on impulse buying. It differs primarily for male and female shoppers because female shoppers do this due to their likeness and spontaneous attraction to colorful fancy products.

On the other hand, an increase in the income level of consumers makes them more prodigal while spending and influencing to buy those products which are not included in the plan. Also, different variables such as an advertisement on print media, visual media, advertising 3-D effect, advertising celebrities, pamphlets and hoarding of different products through organizing events affect the majority of respondents. It influences positively onto impulse buying that reflects a pivotal bonding among respondents like impulse advertising campaign and impulse buying behaviours to enhance the impulse purchase decisions (Cham, Ng, Lim, \& Cheng, 2018; Baker, Moschis, Rigdon \& Fatt, 2016; Jamal, \& Lodhi, 2015; Giovannini, Xu, \& Thomas, 2015; Aruna, \& Santhi, 2015; Bakirtas, Bakirtas \& Cetin, 2015). The type of product plays an important role in impulse buying, especially among the young generation. Also, for computer peripherals, a higher tendency to impulse buying involves predicting as good for different brands products. Another major finding outlines that the internet is competing for a new way of marketing to introduce products while having impulse buying behaviour in mind (Chen, 2008; Applebaum, 1951). According to Rook (1987), impulse buying behaviour with descriptors like intense, exciting, spontaneous, urge to buy with purchaser often ignores the consequences of further research development. In the present study, discuss impulse buying behaviour as a trait rather than a purchase decision classification (Arshed et al., 2019; Arshed, Riaz, Khan, et al., 2017). Without previous knowledge of a new intention or product to purchase a certain item, a buyer must be exposed to suggestions or stimuli connected to the satisfaction of a need or want from that purchase. This identifies different kinds of environmental/sensory and internal stimuli that indicate activating impulse buying. Internal indications may include positive and negative respondents' feeling situations and environmental/sensory include retail setting, marketing mix and marker-controlled indications (Husnain et al., 2019; Cham et al., 2018; Sangalang \& Siochi, 2017; Badgaiyan et al., 2016; Turkyilmaz, Erdem, \& Uslu, 2015; Cho, Ching, \& Luong, 2014; V.R, 2014; Youn \& Faber, 2000; Puri, 1996; Rook \& Fisher, 1995). 


\section{METHODS}

As the objective of the study is to find out the different factors which affect consumers for unplanned buying in departmental Stores of Lahore, so we have taken impulse buying as a depended variable while Physical Environment, Promotional \& Advertisement, Emotions, Selling Behavior and Price are best possible independent variables.

\section{Sample Data}

The sample represents the target customers that are addressed in the whole study. The target population was 250 different customers at three different departmental stores in Lahore; 150 questionnaires are distributed to different customers in Hyperstar, Metro cash \& carry and Al-Fateh. Around 13 of our collected samples were discarded due to incompletion and other errors. It finds the phenomenon studied in this study of unplanned buying behaviors, and the questionnaire identifies the dependent variables. The questionnaire on impulse buying is directly related to the theoretical framework

\section{Questionnaire}

Based on extant literature and the hypotheses developed through the theory generation phase of this research, a 30-item multi-indicator questionnaire was developed. The initial questionnaire was assessed for clarity, face validity, and necessary completion time by authors who had been involved in the quantitative data gathering phase of this research. The factors enclosed in the questionnaire are stated below; the questionnaires are adapted from these studies.

\section{External Factors}

Hausman (2000) explained that some situations and retail atmosphere influence both in-store responses

and the consumers' future store choice decisions because of the changing and dynamic nature of expectations, preferences, and behavior. These environmental variables are merchandising (Han et al., 1991), In-Store promotions (Gutierrez, 2004), People (Ghosh et al., 2010), Advertisement (Srinivasa, 2008), Lightning (Areni \& Kim, 1994; Summers \& Hebert; 2001; Magnum, 1998), and other factors like music, fragrance, colors etc.

\section{Internal Factors}

Several internal factors drive consumers to buy unintentionally. Moods, and Emotions (Watson \& Tellegen, 1985; Beatty \& Ferrell, 1998; Hausman, 2000; Rook et al., 1993; Youn \& Faber, 2000), SelfImage (Sirgy, 1982), Culture and Regret (Piron, 1991), Shopping Enjoyment (Beatty \& Ferrell, 1998).

\section{Price Effect}

Stern (1962), in his studies, realized that the products which are purchased impulsively often have a low price.

\section{Research Design}

The research design is the master plan of a research study (Hair et al., 2003). It lays out the structure, procedures, and data analysis of the research (Leedy \& Ormrod, 2005). The purpose of the study is exploratory because our objectives are to show that such type of study has not been studied more clearly before. Exploratory research helps us to examine the best results to meet our study's objectives, further in this study, correlational and regression-based investigation were used to check the association and relationship between 1 dependent and multiple independent variables, the interference toward this research is minimal because its research the natural environment of the organization with minimum interference and the study is more accurate because it is set a non-contrived study in all stores and distributed the questionnaire in a natural environment of stores. Further, we have operationalized our study to measure the psyche of buyers toward impulse buying to get such results. The survey approach has been taken in this study through convenience sampling. We had distributed 250 questionnaires to different customers in 
Hyper star, Metro cash \& carry and Al-Fateh. Customers were asked to complete the questionnaire immediately, and the customer answered the questions accordingly.

Lastly, since all the indicators are on the Likert scale, this study estimates median regression, which is more appropriate for ordinal variables. A similar study assessing the shopping trends using the quantile regression method for robust estimates (Lin \& Lin, 2007).

\section{DATA ANALYSIS AND RESULTS}

The Cronbach's alpha reliability test checks whether the respondents' response is consistent with that of the construct. The minimum value for the variables is above 0.7 . The results are indicating that all scales are accepted because the value of the reliability test is 0.831 , closer to 1 (Calluna, Vulgaries, \& Nasurdin, 2010). Hence, the measures used in this study were considered highly reliable.

Table 2 provides the descriptive statistics of the variable used in the study. Here we can see that all the variables' mean value is higher than the standard deviation, which means that all the variables are under dispersed and scattered closely around their mean values. While observing the skewness and kurtosis value, it can be seen that none of the variables is normally distributed. Figure 1 and 2 confirms that the dependent variable is not normally distributed. Table 2 of correlation coefficients confirm that all the proposed independent variables are positively and significantly correlated with the impulse buying behavior of individuals. Figure 3 compares the gender-wise frequency of impulse buying, and here we can see that males are more prone to impulse buying than females in our sample.

TABLE 1

\section{DESCRIPTIBE STATISTICS}

\begin{tabular}{|c|c|c|c|c|c|c|c|c|c|}
\hline & \multirow{2}{*}{$\begin{array}{l}\mathrm{N} \\
\text { Statistic }\end{array}$} & \multirow{2}{*}{$\begin{array}{l}\text { Minimum } \\
\text { Statistic }\end{array}$} & \multirow{2}{*}{$\begin{array}{l}\text { Maximum } \\
\text { Statistic }\end{array}$} & \multirow{2}{*}{$\begin{array}{l}\text { Mean } \\
\text { Statistic }\end{array}$} & \multirow{2}{*}{$\begin{array}{l}\text { Std. } \\
\text { Dev. } \\
\text { Statistic }\end{array}$} & \multicolumn{2}{|c|}{ Skewness } & \multicolumn{2}{|l|}{ Kurtosis } \\
\hline & & & & & & Statistic & $\begin{array}{l}\text { Std. } \\
\text { Error }\end{array}$ & Statistic & $\begin{array}{l}\text { Std. } \\
\text { Error }\end{array}$ \\
\hline IMPULSE BUYING & 250 & 1.00 & 5.00 & 3.3088 & .70637 & -.079 & .154 & -.047 & .307 \\
\hline $\begin{array}{l}\text { PHYSICAL } \\
\text { ENVIRONMENT }\end{array}$ & 250 & 1.00 & 5.00 & 3.1872 & .69709 & -.138 & .154 & .156 & .307 \\
\hline $\begin{array}{l}\text { PROMOTIONS \& } \\
\text { ADVERTISEMENTS }\end{array}$ & 250 & 1.00 & 4.60 & 3.1432 & .72509 & -.717 & .154 & .429 & .307 \\
\hline EMOTIONS & 250 & 1.00 & 5.00 & 3.3368 & .66005 & -.211 & .154 & .392 & .307 \\
\hline $\begin{array}{l}\text { SELLING } \\
\text { BEHAVIOUR }\end{array}$ & 250 & 1.40 & 5.00 & 3.3024 & .71860 & -.276 & .154 & .054 & .307 \\
\hline $\begin{array}{l}\text { BUYING } \\
\text { BEHAVIOR }\end{array}$ & 250 & 1.20 & 5.00 & 3.5552 & .74849 & -.365 & .154 & .359 & .307 \\
\hline Gender & 250 & 1 & 2 & 1.50 & .501 & -.016 & .154 & -2.016 & .307 \\
\hline Age & 250 & 1 & 2 & 1.20 & .404 & 1.478 & .154 & .186 & .307 \\
\hline Marital Status & 250 & 1 & 4 & 1.36 & .686 & 2.033 & .154 & 3.718 & .307 \\
\hline
\end{tabular}


FIGURE 1

BOX \& WHISKER PLOT

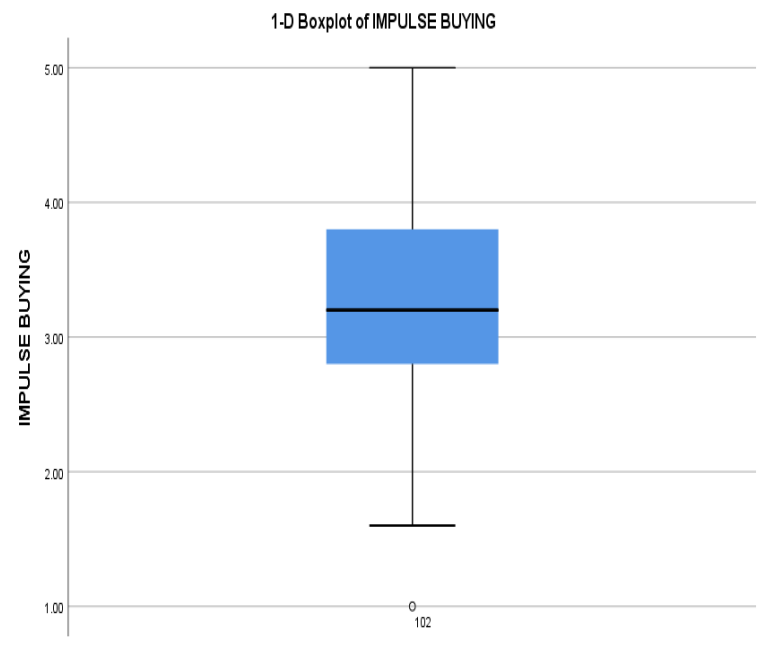

FIGURE 2

HISTOGRAM

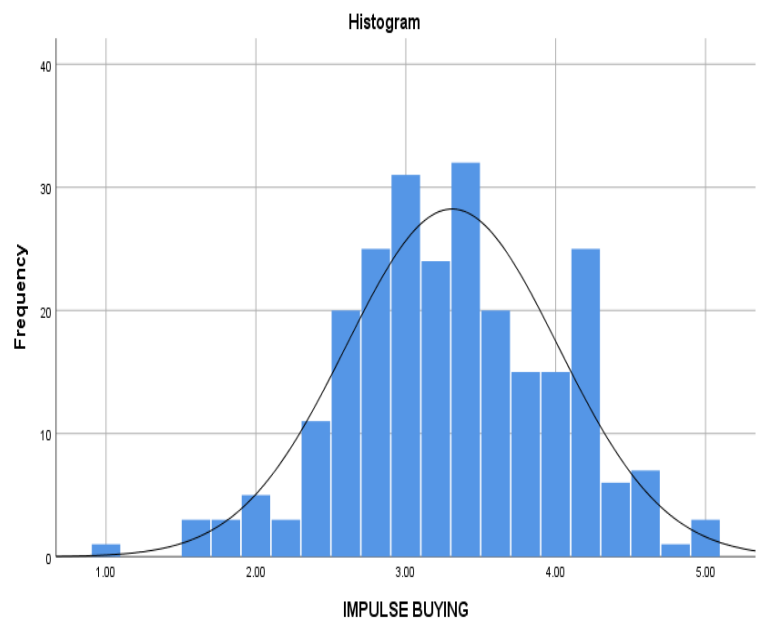

78 Journal of Applied Business and Economics Vol. 23(4) 2021 


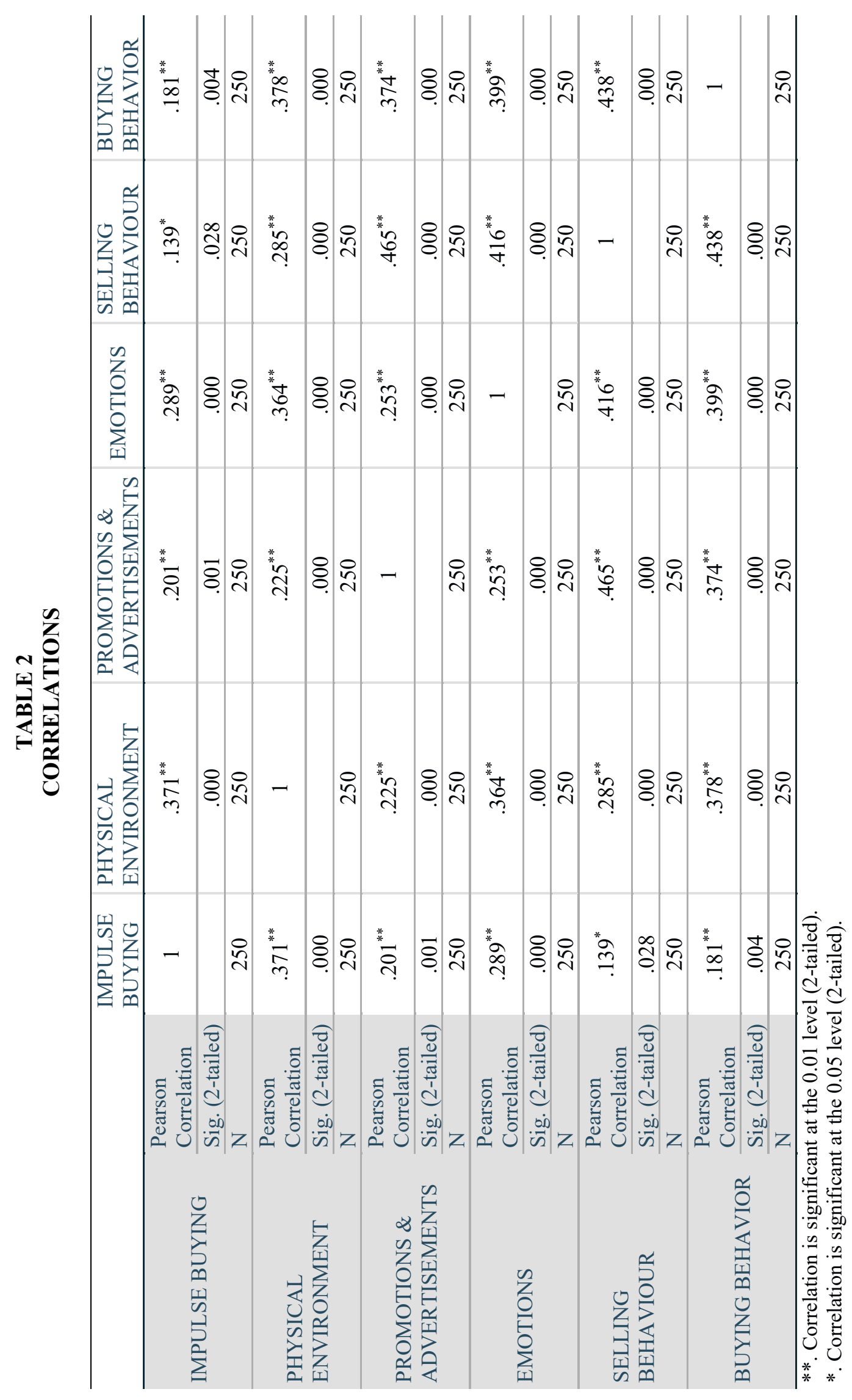

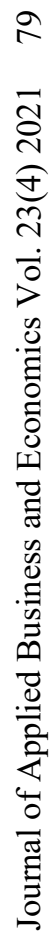


FIGURE 3

POPULATION PYRAMIDS COUNT OF IMPULSE BUYING BY GENDER

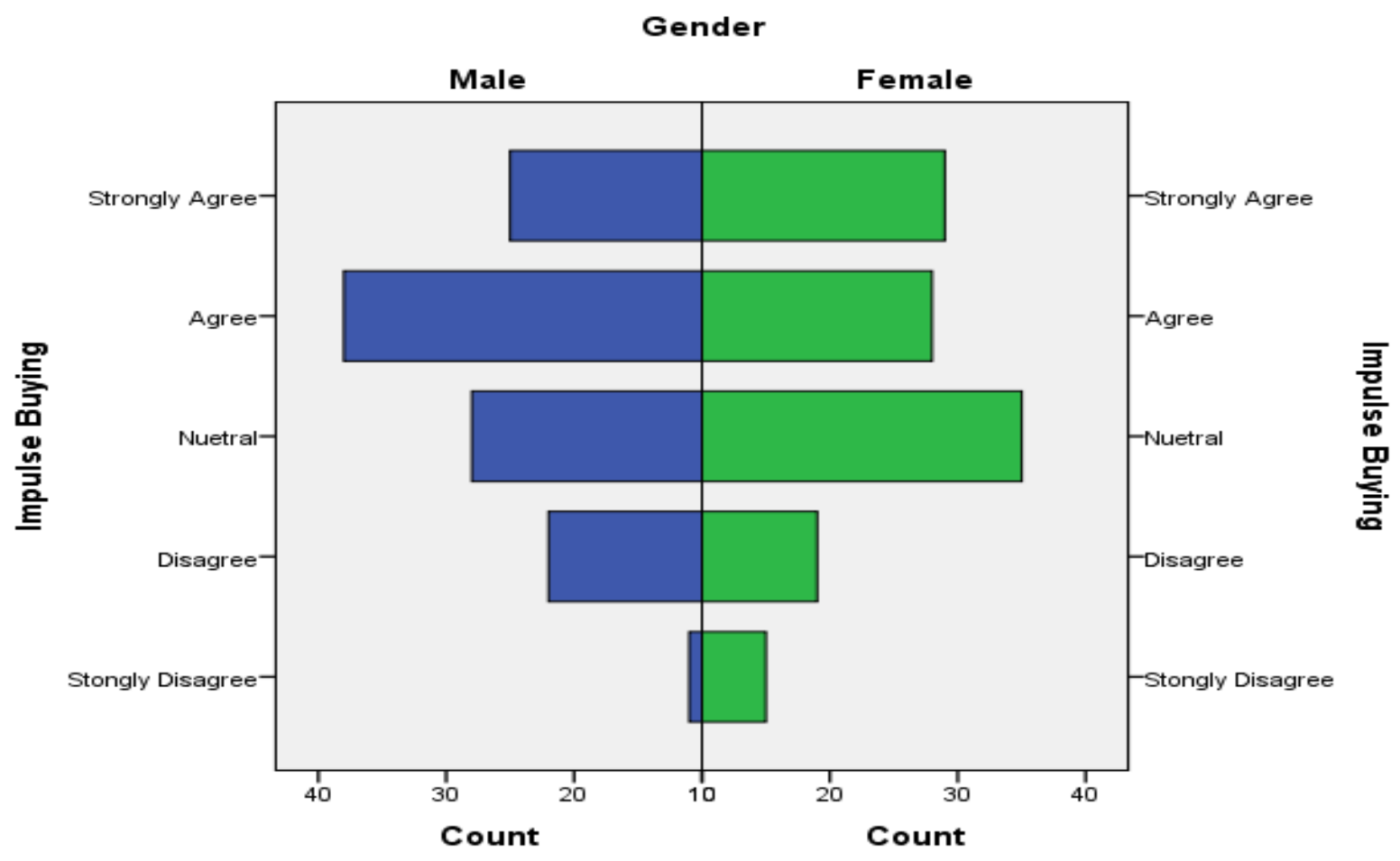

While moving to the median regression, the statistics show that its $\mathrm{R}$ Squared is 0.126 , indicating that the proposed variables are explaining $12.6 \%$ of the variation in the impulse buying behavior. Table 3 reports the coefficients of the median regression. Here we can see that only the indicators like physical environment, promotions \& advertisements, and emotions have a significant positive effect on impulse buying. Out of these indicators, the physical environment is most effective in increasing impulse buying. Surprisingly, this study points out that the indicator for gender, age and marital status of the individuals are not a significant factor in determining impulse buying. This points to the fact that the customers in Lahore are following the herd or word of mouth such that their individual characteristics are not explaining the impulsive buying behavior.

\section{DISCUSSION AND CONCLUSION}

For a developing country like Pakistan, if impulse buying behavior is predominant, especially when the buying is mainly related to imported goods, then it takes a tool on the economy. At the micro-level, it will disturb the monthly balance of the households. It will disturb the country's balance of payments at the macro-level, leading to an exchange rate devaluation-based debt burden. Consequently, there will be an increase in market prices as exchange rate devaluation leads to an increase in import-based commodities. To curtail the major issue, this study focuses on the micro-level issue that, if not handled, in aggregation causes the macro-level issue. The regression analysis idea is to identify the causes of impulse buying behavior so that government can focus on the awareness and policies that curb the unethical or illegal impulse buying inducement by the shopping superstores. 
TABLE 3

MEDIAN REGRESSION

\begin{tabular}{|c|c|c|c|c|c|c|c|}
\hline \multicolumn{8}{|c|}{ Parameter Estimates $(q=0.5)^{a, b}$} \\
\hline Parameter & Coefficient & $\begin{array}{l}\text { Std. } \\
\text { Error }\end{array}$ & $\mathrm{t}$ & df & Sig. & $\begin{array}{l}95 \% \text { Con } \\
\text { Lower } \\
\text { Bound }\end{array}$ & $\begin{array}{l}\text { nce Interval } \\
\text { Upper } \\
\text { Bound }\end{array}$ \\
\hline (Intercept) & 1.398 & .4614 & 3.030 & 239 & .003 & .489 & 2.307 \\
\hline $\begin{array}{l}\text { PHYSICAL } \\
\text { ENVIRONMENT }\end{array}$ & .286 & .0756 & 3.783 & 239 & .000 & .137 & .435 \\
\hline $\begin{array}{l}\text { PROMOTIONS } \& \\
\text { ADVERTISEMENTS }\end{array}$ & .184 & .0750 & 2.452 & 239 & .015 & .036 & .332 \\
\hline EMOTIONS & .177 & .0828 & 2.135 & 239 & .034 & .014 & .340 \\
\hline $\begin{array}{l}\text { SELLING } \\
\text { BEHAVIOUR }\end{array}$ & -.076 & .0813 & -.938 & 239 & .349 & -.236 & .084 \\
\hline $\begin{array}{l}\text { BUYING } \\
\text { BEHAVIOR }\end{array}$ & .085 & .0765 & 1.117 & 239 & .265 & -.065 & .236 \\
\hline$[\mathrm{Age}=1]$ & -.171 & .1608 & -1.061 & 239 & .290 & -.487 & .146 \\
\hline$[$ Age $=2]$ & $0^{\mathrm{c}}$ & . & . & . & - & . & . \\
\hline [Gender $=1]$ & .009 & .0981 & .089 & 239 & .929 & -.185 & .202 \\
\hline [Gender $=2]$ & $0^{\mathrm{c}}$ & & . & 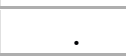 & 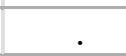 & . & 2 \\
\hline [Marital Status=1] & -.134 & .3506 & -.382 & 239 & .703 & -.825 & .557 \\
\hline [Marital Status=2] & -.147 & .3537 & -.416 & 239 & .678 & -.844 & .550 \\
\hline [Marital Status=3] & .273 & .3905 & .699 & 239 & .486 & -.497 & 1.042 \\
\hline [Marital Status=4] & $0^{\mathrm{c}}$ & & & & & & \\
\hline
\end{tabular}

a. Dependent Variable: IMPULSE BUYING

b. Model: (Intercept), PHYSICAL ENVIRONMENT, PROMOTIONS \& ADVERTISEMENTS, EMOTIONS, SELLING BEHAVIOUR, BUYING BEHAVIOR, Age, Gender, Marital Status

c. Set to zero because this parameter is redundant.

This research study investigated the impact of physical environment, promotion \& advertisement, emotion, buying behavior and selling behavior on Impulse buying. Literature has indicated them as major inducing factors which are causing impulse buying. The correlation and regression estimates explained that there is a positive link between the proposed independent variables and impulse buying behavior. Hence it allows us to study how these independent variables are being used by the shopping superstores and curb any unethical or illegal means.

For the case of the physical environment, regulators must ensure that there should not be extravagant expenditures on the surrounding and ambiance which are inducing the impulse buying. These expenditures to increase attractiveness via physical environment are levied from the buyers in terms of profit. Similar is the case with promotions and advertisements. These expenses, even though they motivate buyers to buy, but are charged from his pocket. Hence, there should be a limit to what a shopping superstore could spend on designing the store so that their cost of providing the service should be curtailed, causing price inflation.

The other dimension which is significantly explaining impulsive buying behavior is emotions. The questionnaire highlights that the motions are drawn from happiness, family, society and brand image. The only way to minimize the effect of emotion on impulse buying is to increase the awareness of household budget management economics. The knowledge regarding the composition of assets and liabilities of the household explains how their present and future income affects their welfare. The government should provide voluntary and accessible financial literacy to the masses to channel any idle savings channeled to investments rather than impulsive consumption. This way, the economy will benefit in two ways; first, there will be a decrease in consumption, reducing inflationary pressures on products. Second, there will be a 
boost in production, which will reduce inflation and dependency on imported products. The abovementioned policy suggestions would eventually lighten the pressure on the household earner's income and ease the balance of payment \& debt burden on the economy.

This study also recommends expanding the scope of the study to other shopping hubs of the country and bifurcate the impulse buying in terms of import-based goods and local goods to be targeted separately and efficiently.

\section{REFERENCES}

Ahmad, M.B., Ali, H.F., Malik, M.S., Humayun, A.A., \& Ahmad, S. (2019). Factors affecting impulsive buying behavior with mediating role of positive mood: An empirical study. European Online Journal of Natural and Social Sciences, 8(1), 7-35.

Alauddin, M., Hossain, M.M., Ibrahim, M., \& Hoque, M.A. (2015). Perceptions of consumer impulse buying behavior in the super store: A case study of some selected super store in Bangladesh. Asian Social Science, 11(9), 68.

Ali, A., \& Hasnu, S. (2013). An Analysis of In-store Shopping Environment on Consumers' impulse Buying: Evidence from Pakistan. Retrieved June 2017, from www.researchgate.net/publications/279461448, 560-570

Ali, S.W., \& Sudan, S. (2018). Influence of cultural factors on impulse buying tendency: A study of Indian consumers. Vision, 22(1), 68-77.

Applebaum, W. (1951). Studying customer behavior in retail stores. Journal of Marketing, 16(2), 172178.

Areni, C.S., \& Kim, D. (1994). The influence of in-store lighting on consumers' examination of merchandise in a wine store. International Journal of Research in Marketing, 11(2), 117-125.

Arshed, N., Alamgir, S., \& Aziz, O. (2017). Structural Determinants of Poverty in Pakistan. International Journal of Economics and Financial Research, 3(1), 1-7.

Arshed, N., Hassan, D.M.S., \& Aziz, O. (2020). Does Income Inequality Lead to Education Inequality? UMT Education Review (UER), 3(1), 45-68. https://doi.org/10.32350/uer.31.03

Arshed, N., Hassan, M.S., Grant, K.A., \& Aziz, O. (2019). Are Karachi Stock Exchange Firms Investment Promoting? - Evidence of Efficient Market Hypothesis Using Panel Cointegration. Asian Development Policy Review, 7(2), 52-65. https://doi.org/10.18488/journal.107.2019.72.52.65

Arshed, N., Riaz, S., Hassan, M.S., \& Aziz, O. (2017). Consequences of Agency Cost In Light of Maqasid Al Shariah. Australasian Journal of Islamic Finance and Business, 1(1), 19-27.

Arshed, N., Riaz, S., Khan, T.M., \& Aziz, O. (2017). Financial disintermediation and Profitability of Global Islamic Banks. European Journal of Islamic Finance, (7). https://doi.org/10.13135/2421$2172 / 2067$

Aruna, S., \& Santhi, P. (2015). Impulse Purchase Behavior among Generation-Y. IUP Journal of Marketing Management, 14(1), 21-38.

Atulkar, S., \& Kesari, B. (2018). Role of consumer traits and situational factors on impulse buying: Does gender matter? International Journal of Retail \& Distribution Management, pp. 386-405.

Azim, A. (2013). Effect of dynamic environment, customers' tendency towards promotion and new experiences on impulse buying. Management and Administrative Sciences Review, 2(3), 281-292.

Aziz, O., Grant, K.A., \& Arshed, N. (2020). Does Entrepreneurial Activity Assist in the Alleviation of Poverty? ProQuest, 22(7), 114-132.

Badgaiyan, A.J., \& Verma, A. (2015). Does the urge to buy impulsively differ from impulsive buying behavior? Assessing the impact of situational factors. Journal of Retailing and Consumer Services, 22, 145-157.

Badgaiyan, A.J., Verma, A., \& Dixit, S. (2016). Impulsive buying tendency: Measuring important relationships with a new perspective and an indigenous scale. IIMB Management Review, 28(4), 186-199. 
Baker, A.M., Moschis, G.P., Rigdon, E.E., \& Fatt, C.K. (2016). Linking family structure to impulsecontrol and obsessive-compulsive buying. Journal of Consumer Behaviour, 15(4), 291-302.

Bakirtas, H., Bakirtas, I., \& Çetin, M.A. (2015). Effects of Utilitarian and Hedonic Shopping Value and Consumer Satisfaction on Consumer Behavioral Intentions. Ege Akademik Bakis, 15(1), 91-98.

Bashir, S., Zeeshan, M., Sabbar, S., Hussain, R.I., \& Sarki, I.H. (2013). Impact of cultural values and life style on impulse buying behavior: A case study of Pakistan. International Review of Management and Business Research, 2(1), 193.

Beatty, S.E., \& Ferrell, M.E. (1998). Impulse buying: Modeling its precursors. Journal of Retailing, 74(2), 169-191.

Brimblecombe, J., Ferguson, M., Chatfield, M.D., Liberato, S.C., Gunther, A., Ball, K., \& Leach, A.J. (2017). Effect of a price discount and consumer education strategy on food and beverage purchases in remote Indigenous Australia: A stepped-wedge randomized controlled trial. The Lancet Public Health, 2(2), e82-e95.

Buaphiban, T., \& Truong, D. (2017). Evaluation of passengers' buying behaviors toward low cost carriers in Southeast Asia. Journal of Air Transport Management, 59, 124-133.

Cham, T.H., Ng, C.K.Y., Lim, Y.M., \& Cheng, B.L. (2018). Factors influencing clothing interest and purchase intention: A study of Generation Y consumers in Malaysia. The International Review of Retail, Distribution and Consumer Research, 28(2), 174-189.

Chen, T. (2008). Online impulse buying and product involvement. Communications of the IBIMA, 5, 7481.

Cho, J., Ching, G.S., \& Luong, T.H. (2014). Impulse buying behavior of Vietnamese consumers in supermarket setting. International Journal of Research Studies in Management, 3(2), 33-50.

Ghaffar, A., Munir, M., Aziz, O., Alhajj, R., \& Sanaullah, A. (2020). An Assessment of the Smart COVID-19 Approach to Lockdown and its Empirical Evidence. Empirical Economic Review, 3(2), 31-61.

Ghosh, P., Tripathi, V., \& Kumar, A. (2010). Customer expectations of store attributes: A study of organized retail outlets in India. Journal of Retail \& Leisure Property, 9(1), 75-87.

Giovannini, S., Xu, Y., \& Thomas, J. (2015). Luxury fashion consumption and generation Y consumers: Self, brand consciousness, and consumption motivations. Journal of Fashion Marketing and Management, 19(1), 22-40.

Grant, K.A., Aziz, O., \& Arshed, N. (2019, April 30). The Impact of Entrepreneurial Activity on Poverty Alleviation. 39th International Scientific Conference on Economic and Social Development"Sustainability from an Economic and Social Perspective." Economic and Social Development, Lisbon, Portugal. Retrieved from https://www.researchgate.net/publication/333079300_The_Impact_of_Entrepreneurial_Activity_ on_Poverty_Alleviation

Grant, K.A., Croteau, M., \& Aziz, O. (2019a). Fact vs. Fiction: The Role of Angel Investment in New Venture Survival. ISPIM Conference Proceedings. Manchester.

Grant, K.A., Croteau, M., \& Aziz, O. (2019b). The Survival Rate of Startups Funded by Angel Investors. I-INC WHITE PAPER SERIES: MAR, pp. 1-21.

Gutierrez, B.P.B. (2004). Determinants of planned and impulse buying: The case of the Philippines. Asia Pacific Management Review, 9(6), 1061-1078.

Han, Y.K., Morgan, G.A., Kotsiopulos, A., \& Kang-Park, J. (1991). Impulse buying behavior of apparel purchasers. Clothing and Textiles Research Journal, 9(3), 15-21.

Hanif, N., Arshed, N., \& Aziz, O. (2020). On interaction of the energy: Human capital Kuznets curve? A case for technology innovation. Environment, Development and Sustainability, 22(8), 7559-7586. https://doi.org/10.1007/s10668-019-00536-9

Hausman, A. (2000). A multi-method investigation of consumer motivations in impulse buying behavior. Journal of Consumer Marketing, 17(5), 403-426. 
Husnain, M., Rehman, B., Syed, F., \& Akhtar, M.W. (2019). Personal and in-store factors influencing impulse buying behavior among generation Y consumers of small cities. Business Perspectives and Research, 7(1), 92-107.

Husnain, M., Rehman, B., Syed, F., \& Akhtar, M.W. (2019). Personal and in-store factors influencing impulse buying behavior among generation Y consumers of small cities. Business Perspectives and Research, 7(1), 92-107.

Jamal, M., \& Lodhi, S. (2015). Consumer shopping behavior in relation to factors influencing impulse buying: A case of superstores in Karachi, Pakistan. International Journal of Scientific and Research Publications, 5(2), 41.

Khawaja, L., (2018). Factors influencing customer buying behavior towards impulse buying. The International Journal of Business \& Management, 6(6), 245-258.

Lin, K.C., \& Lin, C.M. (2007). The demand for lottery expenditure in Taiwan: A quantile regression approach. Economics Bulletin, 4(42), 1-11.

Mahalakshmi, P., \& Kathiravan, C. (2019). Exploring the impulse buying behaviour of e-retail business environment in current scenario. Journal of Research Trends in Management, pp. 141-146.

Mangum, S.R. (1998). Effective constrained illumination of three-dimensional, light-sensitive objects. Journal of the Illuminating Engineering Society, 27(2), 115-131.

Muruganantham, G., \& Bhakat, R.S. (2013). A review of impulse buying behavior. International Journal of Marketing Studies, 5(3), 150-160.

Parsad, C., Prashar, S., \& Tata, V.S. (2017). Understanding nature of store ambiance and individual impulse buying tendency on impulsive purchasing behaviour: An emerging market perspective. Decision, 44(4), 297-311.

Piron, F. (1991). Defining impulse purchasing. ACR North American Advances, 18, 509-514.

Pornpitakpan, C., Yuan, Y., \& Han, J.H. (2017). The effect of salespersons' retail service quality and consumers' mood on impulse buying. Australasian Marketing Journal (AMJ), 25(1), 2-11.

Prashar, S., Parsad, C., \& Vijay, T.S. (2017). Segmenting young Indian impulsive shoppers. Journal of International Consumer Marketing, 29(1), 35-47.

Puri, R. (1996). Measuring and modifying consumer impulsiveness: A cost-benefit accessibility framework. Journal of Consumer Psychology, 5(2), 87-113.

Romeen, S., \& Jocelyn, S. (2017, June 20-22). Factoring Influencing Consumer Impulse Buying Behaviour in the fifth District of Cavite. DLSU Research Congress, pp. 1-6.

Rook, D.W., \& Fisher, R.J. (1995). Normative influences on impulsive buying behavior. Journal of Consumer Research, 22(3), 305-313.

Sangalang, R.A., \& Siochi, J. (2017). Factors influencing consumers' impulse buying behavior in the fifth district of Cavite. In DLSU Research Congress (pp. 1-6).

Sirgy, M.J. (1982). Self-concept in consumer behavior: A critical review. Journal of Consumer Research, 9(3), 287-300.

Srinivasa, D. (2008). Advertisements do they match consumer preferences? Marketing Mastermind, pp. $59-62$.

Stern, H. (1962). The significance of impulse buying today. Journal of Marketing, 26(2), 59-62.

Summers, T.A., \& Hebert, P.R. (2001). Shedding some light on store atmospherics: Influence of illumination on consumer behavior. Journal of Business Research, 54(2), 145-150.

Tara, N., Arshed, N., Aziz, O., \& Yamin, M. (2020). Can Financial Assistance Mediate the Training and Human Capital Relationship for Pakistani Women Micro Entrepreneurs? International Journal of Economics and Financial Issues, 10(4), 80-87. https://doi.org/10.32479/ijefi.9833

Turkyilmaz, C.A., Erdem, S., \& Uslu, A. (2015). The Effects of Personality Traits and Website Quality on Online Impulse Buying. Procedia-Social and Behavioral Sciences, 175(2015), 98-105.

V., R. (2014, October). Study on impulse buying behavior of fashion-oriented Indian youth with respect to visual merchandising. International Journal of Management and Social Science Research Review, 1(4), 235-239. 
Valaei, N., \& Nikhashemi, S.R. (2017). Generation Y consumers' buying behaviour in fashion apparel industry: A moderation analysis. Journal of Fashion Marketing and Management: An International Journal, 21(4), 523-543.

Vishnu, P., \& Raheem, A.R. (2013). Factors influencing impulse buying behavior. European Journal of Scientific Research, 100(3), 67-79.

Vyas, H. (2015). Packaging design elements and users perception: A context in fashion branding and communication. Journal of Applied Packaging Research, 7(2), 95-107.

Watson, D., \& Tellegen, A. (1985). Toward a consensual structure of mood. Psychological Bulletin, 98(2), 219-235.

Youn, S., \& Faber, R.J. (2000). Impulse buying: Its relation to personality traits and cues. ACR North American Advances, 27, 179-185.

\section{APPENDIX}

This questionnaire is for a research paper designed to access the factors affecting consumer impulse buying (unplanned buying) behavior in Lahore (Departmental store). Your information will be kept confidential, and the responses will be aggregated for analysis. We appreciate your participation.

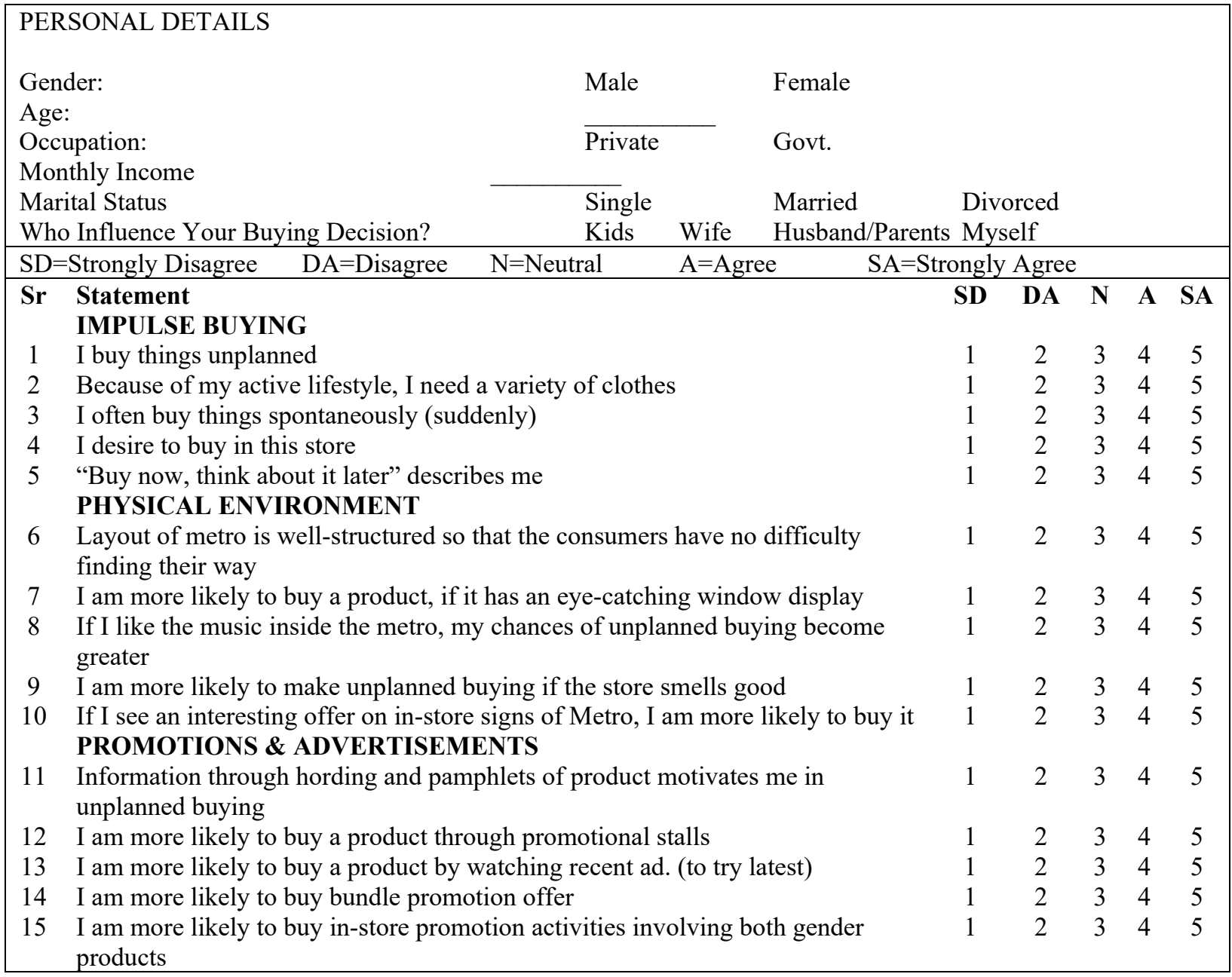




\begin{tabular}{|c|c|c|c|c|c|c|}
\hline & EMOTIONS & & & & & \\
\hline 16 & I am more likely to do unplanned buying for brands which has my family trust & 1 & 2 & 3 & 4 & 5 \\
\hline 17 & I buy unplanned products if the brand has a good image in market & 1 & 2 & 3 & 4 & 5 \\
\hline 18 & I buy unplanned things that make me feel (happy, superior, joy) & 1 & 2 & 3 & 4 & 5 \\
\hline 19 & I am more likely to buy unplanned products by seeing others buying & 1 & 2 & 3 & 4 & 5 \\
\hline 20 & $\begin{array}{l}\text { I am more likely to buy unplanned products when I am depressed over } \\
\text { situations } \\
\text { SELLING BEHAVIOR }\end{array}$ & & & & & \\
\hline 21 & If the behavior of the sales person is friendly, it helps me in unplanned buying & 1 & 2 & 3 & 4 & 5 \\
\hline 22 & $\begin{array}{l}\text { I am more intended to buy online if the selling technique sounds reasonable/ } \\
\text { website }\end{array}$ & 1 & 2 & 3 & 4 & 5 \\
\hline 23 & $\begin{array}{l}\text { I am more willing to make impulse buying if staff attitude and willingness to } \\
\text { help }\end{array}$ & 1 & 2 & 3 & 4 & 5 \\
\hline 24 & $\begin{array}{l}\text { I am more into impulse shopping if brand offers Liberal Exchange and refund } \\
\text { police }\end{array}$ & 1 & 2 & 3 & 4 & 5 \\
\hline 25 & $\begin{array}{l}\text { I am more into impulse buying if the salesperson's product knowledge is more } \\
\text { relatable } \\
\text { BUYING BEHAVIOR }\end{array}$ & 1 & 2 & 3 & 4 & 5 \\
\hline 26 & I am more likely to buy products unplanned if the discount is available & 1 & 2 & 3 & 4 & 5 \\
\hline 27 & Credit/ Debit cards makes me buy unplanned things more often & 1 & 2 & 3 & 4 & 5 \\
\hline 28 & Various schemes like (buy 1 get 1 free) affect makes me buy more & 1 & 2 & 3 & 4 & 5 \\
\hline 29 & I buy unplanned deals on different occasions (Ramadan, Eid, Weddings offers) & 1 & 2 & 3 & 4 & 5 \\
\hline 30 & I am more into impulse buys if the product catches my eye. & 1 & 2 & 3 & 4 & - \\
\hline
\end{tabular}

